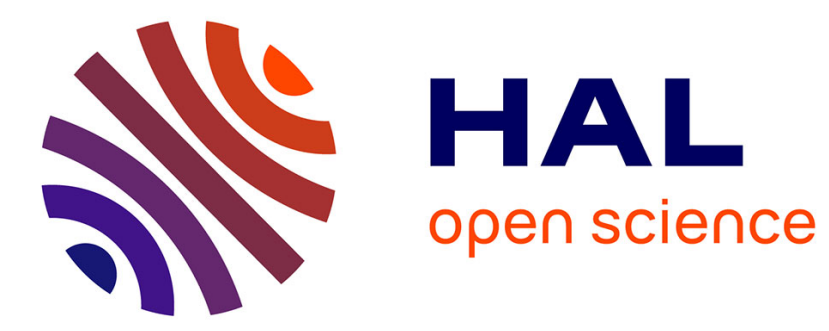

\title{
Extracting Ideal Point Estimates from Actors' Preferences in the EU Constitutional Negotiations
}

Simon Hix, Christophe Crombez

\section{To cite this version:}

Simon Hix, Christophe Crombez. Extracting Ideal Point Estimates from Actors' Preferences in the EU Constitutional Negotiations. European Union Politics, 2005, 6 (3), pp.353-376. $10.1177 / 1465116505054837$. hal-00571716

\section{HAL Id: hal-00571716 \\ https://hal.science/hal-00571716}

Submitted on 1 Mar 2011

HAL is a multi-disciplinary open access archive for the deposit and dissemination of scientific research documents, whether they are published or not. The documents may come from teaching and research institutions in France or abroad, or from public or private research centers.
L'archive ouverte pluridisciplinaire HAL, est destinée au dépôt et à la diffusion de documents scientifiques de niveau recherche, publiés ou non, émanant des établissements d'enseignement et de recherche français ou étrangers, des laboratoires publics ou privés. 


\section{EUP}

European Union Politics

DOI: 10.1177/1465116505054837

Volume 6 (3): 353-376

Copyright@ 2005

SAGE Publications

London, Thousand Oaks CA

New Delhi

\section{KEY WORDS}

- EU constitutional Treaty

- factor analysis

- ideal point estimation

- Intergovernmental

Conference

- NOMINATE

\section{Extracting Ideal Point}

\section{Estimates from Actors'}

Preferences in the EU

\section{Constitutional Negotiations}

\section{Simon Hix}

London School of Economics and Political Science, UK

\section{Christophe Crombez}

Stanford University, USA, and University of Leuven, Belgium

\section{ABSTRACT}

This article uses the Domestic Structures and European Integration (DOSEI) data set of actors' preferences on 65 issues in the 2003-4 Intergovernmental Conference to extract the underlying preferences of the governments, the Commission and the European Parliament on the main dimensions of conflict in the European Union's constitutional negotiations. The analysis starts by comparing the ideal point estimates produced by three 'inductive' techniques: exploratory factor analysis, NOMINATE and Optimal Classification. The results are a series of ideal point estimates that do not correlate well with some simple a priori assumptions about key actors' positions on the reform of the EU. The analysis then proceeds with a 'mixed' deductive/inductive method, in which responses to the survey questions relating to the two exogenous dimensions of constitutional design in a multi-level polity (the 'vertical' and 'horizontal' allocation of power) are used to generate ideal point estimates on these two dimensions. The result is a more intuitive set of ideal point estimates for the 28 main actors in the negotiations. 


\section{Introduction: Towards a 'mixed method' of ideal point estimation}

There are multiple ways of inducing ideal point estimates from survey data. One of the most common methods is factor analysis, which uses the correspondence between actors' preferences on different issues to extract the underlying dimensions of preferences. A different method is to recode each preference on a given question as a binary 'item response', and then apply a nominal scaling method to extract ideal point estimates, such as NOMINATE or Optimal Classification. Nevertheless, these techniques are essentially 'exploratory', or inductive, since no a priori information about the expected relationship between certain issues is used to structure the extraction of dimensions from the data. The danger of such methods is that the extracted ideal point estimates may not match intuitive expectations, because responses on a small number of key issues can be 'polluted' by random responses on a larger number of irrelevant issues.

Alternatively, a purely deductive method could be used. For instance, a small set of exogenous issue dimensions could be identified, and the actors' positions on the issues that relate to these dimensions could be added together to create ideal point estimates for the actors on these dimensions. This is the method used by the Americans for Democratic Action (ADA) to create 'scores' for members of the US Congress from their voting behaviour on the issues the ADA cares about in American politics. ${ }^{1}$ A problem of such purely deductive methods, however, is that they do not allow actors' positions on different issues to be weighted by how far these issues correlate with the underlying dimension in the calculation of ideal point estimates.

Consequently, 'mixed' methods employ a combination of deduction and induction. On the deductive side, a small number of expected dimensions and the specific issues relating to these dimensions can be identified. Then, on the inductive side, in the construction of ideal point estimates, the actors' positions on these issues can be weighted according to how the positions on these issues relate to the main extracted dimension. 'Confirmatory' factor analysis does something similar, by allowing for a set of expected dimensions to be identified, and then seeing how far the issue preferences accord with the expected dimensionality of the issue space.

In this article we try to identify the location of the EU governments, the Commission and the European Parliament on the main dimensions of conflict in the 2003-4 Intergovernmental Conference (IGC) negotiations on the draft constitutional Treaty. We use the positions of these actors on 65 issues in the IGC, as measured in the Domestic Structures and European Integration (DOSEI) data set. We then identify two exogenous dimensions of 
constitutional design, which can be expected to be central conflicts in the design of an EU Constitution: the allocation of power between the centre and the states (which we call the 'vertical dimension'), and the allocation of power between the central institutions (which we call the 'horizontal dimension'). In the third section we compare the results produced by applying three 'inductive' techniques: exploratory factor analysis, NOMINATE and Optimal Classification. We then employ a mixed method similar to confirmatory factor analysis - but, whereas confirmatory factor analysis aims to identify the 'best fit' for describing the dimensionality of a space, our method is designed to extract ideal point estimates on our two exogenous dimensions (Bentler, 1990). After briefly comparing the ideal point estimates produced in the previous sections, we offer a short conclusion.

\section{Vertical and horizontal dimensions of constitutional design}

Lijphart (1999), inter alia, identifies two essential dimensions of the design of democracies, each relating to who has the power to make and enact policy (Powell, 2000; Taagepera, 2003). First, a vertical dimension relates to the degree of centralization of policy competences. At one extreme, all major areas of public policy could fall within the remit of the central institutions, as in a unitary system of government (such as The Netherlands). At the other extreme, the powers of the central institutions could be restricted to a small set of policy competences while the states maintain exclusive rights over many important policy areas and a strong constitutional court has the power to police competence conflicts, as in a decentralized federal system of government (such as the United States).

Second, a horizontal dimension relates to how far a particular political majority is able to enact its policy preferences, for example by forming the executive and controlling a majority in the legislature. At one extreme, a polity can have a single agenda-setter and veto-player, as in the classic 'Westminster' model of single-party government, executive dominance of the legislature and a weak second chamber. At the other extreme, a polity can be designed to have multiple veto-players, either through proportional representation and coalition governments (particularly where a grand coalition is prevalent), or through a separation of powers between the executive (President) and the legislature (Congress), or through 'strong bicameralism', or any combination of these factors (e.g. Tsebelis, 1995, 2002).

These designs determine how easy or difficult it will be to make and change policies. In a centralized/majoritarian model (such as the United 
Kingdom), the central executive has enormous power to change the policy status quo. Conversely, in a decentralized/consensual model (such as Switzerland), the policy competences of the central government are limited, and the executive must construct a large majority to change any policy within its remit. In a centralized/consensual model (such as Finland), the central government has the potential to change any policy, but is constrained by the need to construct an oversized coalition to support policy change. Or, in a decentralized/majoritarian model (such as Canada), the central government can change the policy status quo relatively easily, but in only a limited set of policy areas.

Because decentralized or consensual institutions represent constraints on the power of the central government, constitutional design preferences on these two dimensions often correlate. On one side, an actor who would like to allow for an electoral majority to enact radical policy change (such as a socialist party) is likely to advocate a centralized/majoritarian constitutional design. On the other side, an actor who would like to limit the power of government as much as possible (such as a free market libertarian) is likely to support a decentralized/consensual constitutional design. Nevertheless, the intermediate constitutional mixes may also be consistent with underlying policy preferences. For example, an actor may prefer policy change, but may expect that he or she is more likely to secure change in his or her preferred direction at the local level than at the central level, and so advocate a decentralized/majoritarian model. Equally, an actor may not want policy change, but might feel constrained at the domestic level by policy externalities from neighbouring states, and so prefer a centralized/consensual model.

These four basic constitutional design preferences are present in the debate about the EU Constitution, as Figure 1 illustrates. In the centralized/ majoritarian corner is the classic 'Euro-federalism' model, where major policy

\section{Horizontal allocation of power}

$\begin{array}{ll}\text { Consensus } & \begin{array}{l}\text { Majoritarian } \\ \text { government }\end{array}\end{array}$

\begin{tabular}{|c|c|c|}
\cline { 2 - 3 } $\begin{array}{l}\text { Vertical Centralized } \\
\text { allocation } \\
\text { of power }\end{array}$ & $\begin{array}{c}\text { Union of nation-states } \\
\text { (France) }\end{array}$ & $\begin{array}{c}\text { Euro-federalism } \\
\text { (Belgium) }\end{array}$ \\
\cline { 2 - 3 } Decentralized & $\begin{array}{c}\text { Intergovernmentalism } \\
\text { (United Kingdom) }\end{array}$ & $\begin{array}{c}\text { Decentralized federalism } \\
\text { (new member states?) }\end{array}$ \\
\hline
\end{tabular}

Figure 1 Two underlying dimensions of constitutional bargaining in the EU. 
competences would be passed to the European level and the 'supranational' institutions (the Commission, the European Parliament and the European Court of Justice) would have significant independent powers to shape the policy outcomes. Since the Single European Act, this position has perhaps been held most consistently by successive Belgian governments, as well as by the EU institutions themselves, notably the Commission and the European Parliament. For instance, in the Laeken Convention on the Future of Europe and in the IGC negotiations, the Verhofstadt government argued for new policy competences for the EU (such as a direct EU tax), election of the Commission by the European Parliament, and the extension of the co-decision procedure to almost all policy areas (Norman, 2003).

In the opposite decentralized/consensus government corner is the classic 'intergovernmentalist' model, where only a limited set of policy competences would be allocated to the European level. The governments in the Council would maintain a monopoly on decision-making power over these policies, decided predominantly by unanimity. The European Parliament would be weak. This position has been held most consistently by the United Kingdom. Despite Tony Blair's self-proclaimed pro-European credentials, the British government representatives in the Convention and IGC favoured new constraints on the exercise of policy competences at the EU level (where national parliaments could raise a 'flag' if they were concerned about a breach of the subsidiarity rules), declared a number of 'red line' areas where unanimity voting in the Council would have to be maintained, and opposed any major extension of the powers of the European Parliament (for example over the budget).

In the centralized/consensus corner is a mixed model of government for the EU, which is perhaps best characterized as 'centralized intergovernmentalism'. This position has been held most consistently by France, at least since the Hague Summit in 1969, after Charles de Gaulle was no longer the French President. For instance, in the Convention and IGC, Jacques Chirac argued for a 'Union of Nation-States', where the policy competences of the EU would be broadly defined (including macroeconomic management and space exploration!), but decision-making power would reside in the Council and the European Council and the Commission and the Parliament would remain weak.

Finally, in the decentralized/majoritarian corner is a model of the EU that can be described as 'decentralized federalism'. This position is hard to identify in the debates on the various treaty reforms since the mid 1980s. This is because the negotiations on the Single European Act, the Maastricht Treaty, the Amsterdam Treaty and the Nice Treaty were more about what policy competences should be added to those already existing at the EU level rather 
than what policy powers should be handed back to the member states. Nevertheless, in the negotiations on the constitutional Treaty, several of the new member states seemed to favour this sort of design for the EU, with support for a powerful Commission and Parliament against the Council (which is likely to be dominated by the big member states), but new restrictions on the policy competences of the EU, for example with powers for national parliaments to challenge breaches of a new catalogue of competences.

In other words, it is reasonable to assume that the governments' preferences on the specific issues in the IGC negotiations reflected underlying preferences on these two basic dimensions of constitutional design. We shall first investigate whether this was the case with exploratory factor analysis before applying a mixed deductive/inductive method.

\section{Three inductive techniques}

The input data for our analysis are the positions of the $26 \mathrm{EU}$ governments (the 25 governments that were there at the start of the negotiations plus the new Spanish government elected in March 2004) together with the Commission and the European Parliament on 65 issues in the IGC, as measured in the DOSEI data set. The data were collected through face-to-face interviews with several actors in each of the EU government administrations, the Commission and the European Parliament. Each issue in the survey represented an ordinal three-point or five-point (Likert) scale, and interviewees were asked to locate the position of their government/EU institution at one point on each of the 65 scales. $^{2}$

To extract ideal point estimates for these actors we start by applying three inductive scaling techniques: exploratory factor analysis, NOMINATE and Optimal Classification. Exploratory factor analysis is a widely used technique, which can be applied to these sorts of ordinal response data without any recoding. In contrast, NOMINATE and Optimal Classification were originally developed for the study of roll-call voting in parliaments, and are therefore designed for binary, Yes/No, responses. Hence, to apply these methods to our survey data, the data needed to be recoded into a series of binary response items. For example, an issue where actors are located at five possible positions on a scale $(1,2,3,4$ and 5 , say) is transformed into five separate binary items $(1 \mathrm{Y} / 1 \mathrm{~N}, 2 \mathrm{Y} / 2 \mathrm{~N}, 3 \mathrm{Y} / 3 \mathrm{~N}, 4 \mathrm{Y} / 4 \mathrm{~N}, 5 \mathrm{Y} / 5 \mathrm{~N})$. Recoding the data in this way transformed the 65 scales into 156 binary response items.

NOMINATE utilizes a parametric and stochastic model, and recovers information about individual legislator and roll-call vote characteristics by exploiting the assumption of the probabilistic spatial model that some errors 
are more likely than others. The method also assumes that errors are distributed according to a logistic function, and that errors are independent and identically distributed across both legislators and votes. Developed originally by Keith Poole and Howard Rosenthal (1997) for the study of voting in the United States Congress, NOMINATE has rapidly become one of the standard techniques for estimating actors' ideal points in parliaments and assemblies across the world (Voeten, 2000; Hix, 2001; Schonhardt-Bailey, 2003).

Keith Poole (2000) subsequently developed Optimal Classification as an alternative to NOMINATE. This method does not rely on assumptions about errors to derive ideal point estimates from binary response data. Instead, ideal points are derived by minimizing classification errors. A classification error for an actor on an issue occurs when the legislator's ideal point is such that his or her vote is inconsistent with the cutting-line on the issue (the line that splits the Yes camp from the No camp). The advantage is that no single error or group of errors can bias the overall ideal point estimates. On the downside, though, using a non-parametric method allows only a rank order of actors' ideal points to be recovered. Nevertheless, as Rosenthal and Voeten (2004) show in the case of the French National Assembly, Optimal Classification can produce more reliable ideal point estimates than NOMINATE in environments where voting/preference expression errors are not randomly distributed, for whatever reason.

One problem with both NOMINATE and Optimal Classification, however, is that the substantive meaning of the dimensions produced by these methods is difficult to interpret. With parliamentary roll-call voting data, the usual method is to look at the angle of the 'cutting-line' of some of the key votes. For example, if the cutting-line of most socioeconomic votes crosses the first dimension at approximately 90 degrees, then the first dimension is assumed to represent a set of left-right preferences. These methods produce cutting-line angles for each of the recoded response items from the survey. However, because these items are so specific, as a result of the recoding, it is virtually impossible to interpret the meaning of these angles. Hence, the only way to interpret the substantive content of the dimensions produced by NOMINATE and Optimal Classification in the analysis is to look at the relative locations of the actors on each dimension, and apply some exogenous knowledge about the underlying preferences and interests of the actors.

NOMINATE and Optimal Classification have not been widely applied to survey data. However, preferences expressed in surveys are not inherently different from preferences expressed in parliamentary voting. Hence, it is reasonable to assume that results produced by NOMINATE and Optimal Classification can be compared with results produced by exploratory factor analysis. 


\section{Exploratory factor analysis}

Starting with factor analysis, we applied principal components factor analysis, with varimax rotation to maximize the degree of fit on the first extracted factor. The first result to note is the high dimensionality of the issue space revealed by this method. Specifically, the first factor explained $11.2 \%$ of the variance, the second factor an additional $8.4 \%$, the third factor an additional 7.1\%, and the fourth factor an additional $6.6 \%$. Altogether, it took 13 factors to explain more than $75 \%$ of the variance in preferences on the 65 issues in the IGC negotiations.

Table 1 shows the loadings for the actors' preferences on each issue on the first four factors extracted using this method. ${ }^{3}$ The 10 issues that loaded highest on the first factor were (in declining order of loading on this factor): majority voting on tax harmonization; majority voting on foreign policy; the organization of EU defence; majority voting on defence policy; enhanced cooperation; migration and asylum policies; majority voting on social security; majority voting on social policy; the design of qualified majority voting (QMV); and the initiation of legislation by the European Parliament (which loaded negatively). These were all highly sensitive and divisive issues in the negotiations, where actors seemed to take sides according to whether they favoured a centralized/majoritarian model or a decentralized/consensual model. The former group favoured a common European foreign, defence and migration policy, more majority voting, and more powers for the European Parliament, whereas the latter group favoured the opposite. Nevertheless, several other high-profile issues do not load on this factor, such as the allocation of policy competences between the EU and the member states, whether there should be a single chair of the European Council, or how far the co-decision procedure should be extended.

The second factor also seems to have an identifiable substantive meaning, as five of the 'level of competence' issues load highest on this factor: whether structural and cohesion, agriculture, environment, health, and education policies should be exercised at the EU or national levels. But the third and fourth factors are harder to interpret. The two issues that load highest on the third factor - subsidiarity and the election of the Council President - do not seem to have any necessary connection, as the first issue is central to the vertical allocation of power in the EU polity and the second issue is central to the horizontal allocation of power. Similarly, the four issues that load highest on the fourth factor seem completely unrelated: the Charter of Fundamental Rights; majority voting on structural and cohesion policies; the external representation of the EU; and the budgetary rights of the European Parliament. 
Table 1 Factor loadings using the full set of issues

\section{Factor}

\begin{tabular}{|c|c|c|c|c|}
\hline & & & & \\
\hline Issue & 1 & 2 & 3 & 4 \\
\hline 1: Charter of Fundamental Rights & .003 & .095 & .104 & .885 \\
\hline 2: Subsidiarity & -.003 & .098 & .881 & .112 \\
\hline 3: Religious reference & .224 & .032 & -.127 & -.039 \\
\hline 4: Right to withdraw from the Union & .306 & .312 & -.058 & -.052 \\
\hline 5a: Objectives: Market economy & .367 & -.133 & .063 & .195 \\
\hline 5b: Objectives: Employment & .024 & .277 & -.023 & .013 \\
\hline 5c: Objectives: Competitiveness & .154 & .102 & .068 & -.106 \\
\hline 6: Presidency of the European Council & .076 & -.009 & .047 & -.045 \\
\hline 7: Election of the Council President & -.168 & .335 & .550 & -.358 \\
\hline 8: Design of QMV & .406 & -.061 & .148 & .025 \\
\hline 9: Number of commissioners & .214 & -.311 & -.329 & -.121 \\
\hline 10: Appointment of Commission President & -.088 & -.126 & .080 & -.305 \\
\hline 11: Appointment of Commissioners & .171 & .184 & -.170 & .242 \\
\hline 12: External representation & .261 & .292 & -.034 & .663 \\
\hline 13a: Appointment of Foreign Minister & .068 & -.023 & .059 & .097 \\
\hline 13b: Additional approval by the EP & -.156 & .110 & .171 & .167 \\
\hline 14: ECJ jurisdiction & .093 & .029 & .249 & .144 \\
\hline 15b: Initiative for legislative acts: Parliament & -.402 & -.019 & .282 & .020 \\
\hline 15c: Initiative for legislative acts: Council & .015 & -.096 & -.130 & .157 \\
\hline 15e: Initiative for legislative acts: Citizens & .172 & .088 & .061 & -.086 \\
\hline 16: Enhanced cooperation & .711 & .099 & -.256 & -.124 \\
\hline 17.1: Level of competence: Agriculture & -.103 & .857 & -.047 & .093 \\
\hline $\begin{array}{l}\text { 17.2: Level of competence: Structural and } \\
\text { cohesion policies }\end{array}$ & -.090 & .890 & .156 & .119 \\
\hline $\begin{array}{l}\text { 17.3: Level of competence: Area of freedom, } \\
\text { security and justice }\end{array}$ & .126 & -.209 & .076 & .084 \\
\hline 17.4: Level of competence: Foreign policy & .248 & .062 & -.113 & .017 \\
\hline 17.5: Level of competence: Economic policy & -.056 & .128 & -.103 & .165 \\
\hline 17.6: Level of competence: Tax harmonization & .210 & .188 & .394 & -.110 \\
\hline 17.7: Level of competence: Employment policy & -.041 & .237 & .256 & -.060 \\
\hline 17.8: Level of competence: Social policy & .224 & .331 & -.054 & -.345 \\
\hline 17.9: Level of competence: Health & -.034 & .497 & -.013 & -.110 \\
\hline 17.10: Level of competence: Environment & .002 & .721 & .089 & -.032 \\
\hline 17.11: Level of competence: Education & .046 & .461 & .093 & .007 \\
\hline $\begin{array}{l}\text { 17.12: Level of competence: Research, } \\
\text { technological development and space }\end{array}$ & .074 & .196 & .124 & .152 \\
\hline $\begin{array}{l}\text { 18a.2: Majority voting: Structural and cohesion } \\
\text { policies }\end{array}$ & .052 & -.020 & -.081 & .753 \\
\hline $\begin{array}{l}\text { 18a.3: Majority voting: Area of freedom, security } \\
\text { and justice }\end{array}$ & .219 & -.168 & .007 & .096 \\
\hline 18a.5: Majority voting: Tax harmonization & .861 & -.107 & .044 & -.115 \\
\hline
\end{tabular}


Table 1 Continued

\section{Factor}

\begin{tabular}{|c|c|c|c|c|}
\hline Issue & 1 & 2 & 3 & 4 \\
\hline $\begin{array}{l}\text { 18a.6: Majority voting: Monetary policy } \\
\text { (for the Euro states) }\end{array}$ & .100 & -.023 & .071 & .116 \\
\hline 18a.7: Majority voting: Economic policy & .132 & .018 & .073 & -.221 \\
\hline 18a.8: Majority voting: Employment policy & .185 & -.026 & -.073 & -.035 \\
\hline 18a.9: Majority voting: Social policy & .469 & -.301 & .140 & -.110 \\
\hline 18a.10: Majority voting: Social security rights & .576 & -.153 & .250 & -.172 \\
\hline 18a.11: Majority voting: Common foreign policy & .735 & -.214 & -.045 & .381 \\
\hline 18a.12: Majority voting: Defence policy & .713 & .038 & .137 & .235 \\
\hline 18b.1: Co-decision: Agriculture & -.082 & -.042 & -.137 & .057 \\
\hline $\begin{array}{l}\text { 18b.2: Co-decision: Structural and cohesion } \\
\text { policies }\end{array}$ & -.126 & .049 & -.016 & .226 \\
\hline $\begin{array}{l}\text { 18b.3: Co-decision: Area of freedom, security } \\
\text { and justice }\end{array}$ & -.065 & .045 & .133 & -.100 \\
\hline 18b.4: Co-decision: Internal market & -.327 & .179 & -.050 & -.164 \\
\hline 18b.5: Co-decision: Tax harmonization & .306 & .035 & .055 & -.022 \\
\hline $\begin{array}{l}\text { 18b.6: Co-decision: Monetary policy } \\
\text { (for the euro states) }\end{array}$ & -.204 & -.066 & .243 & .075 \\
\hline 18b.7: Co-decision: Economic policy & -.136 & -.026 & .363 & -.078 \\
\hline 18b.8: Co-decision: Employment policy & .138 & -.274 & .278 & -.173 \\
\hline 18b.9: Co-decision: Social policy & .098 & -.097 & .188 & -.065 \\
\hline 18b.10: Co-decision: Social security rights & .212 & -.085 & .388 & -.081 \\
\hline 18b.11: Co-decision: Common foreign policy & .132 & .105 & -.155 & .145 \\
\hline 18b.12: Co-decision: Defence policy & .132 & .105 & -.155 & .145 \\
\hline 19: Budgetary rights of the EP & .041 & .084 & .135 & .409 \\
\hline 20: Stability and Growth Pact: Flexibility & -.246 & .277 & .059 & .086 \\
\hline 21: Stability and Growth Pact: Debt criterion & .071 & .124 & .231 & -.319 \\
\hline 22: Defence & .735 & -.042 & .025 & .126 \\
\hline 23: External borders & .136 & .336 & -.263 & .021 \\
\hline 24: Migration and asylum & .674 & .103 & -.272 & .080 \\
\hline
\end{tabular}

Note: Method - principal components factor analysis with varimax rotation.

Despite the seemingly logical meaning of the first two factors, the ideal point estimates produced by these dimensions do not seem to accord with a priori intuitions about the relative location of the key protagonists in the IGC. Using the loadings of all the issues on the first two factors to generate ideal points produces a set of actor locations as described in Figure 2. The preference-outliers - Czech Republic, Latvia, Slovakia, Malta, Cyprus, Greece, Italy and Portugal - seem rather strange, because none of these states was reported 


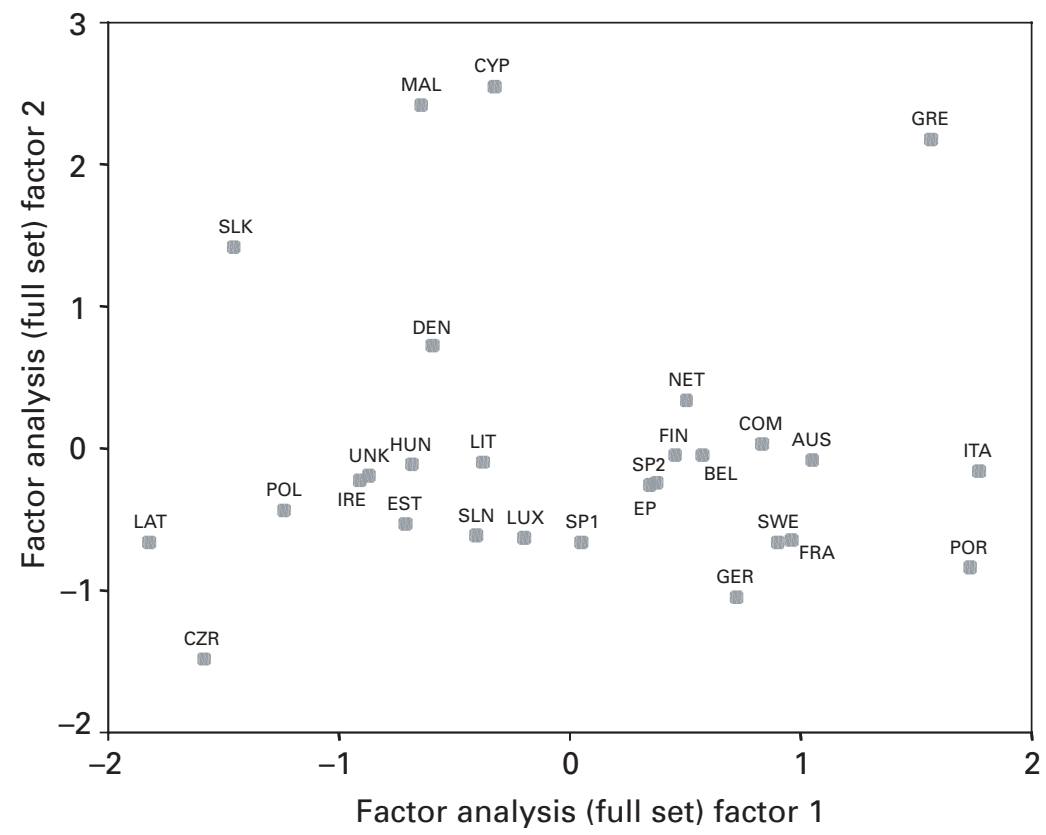

Figure 2 Ideal point estimates using exploratory factor analysis.

Note: SP1 is the Aznar government of Spain, and SP2 is the Zapatero government.

in the press as having particularly difficult preferences to accommodate. Conversely, the actors whom we described as classically representing extreme positions on either the vertical or the horizontal dimension of design (the United Kingdom, France, Belgium or the European Commission), and the two member states that almost derailed the negotiations because of their preference for the Nice status quo on voting weights in the Council (Spain and Poland), are all centrally located in this set of ideal point estimates.

\section{NOMINATE and Optimal Classification}

Applying NOMINATE to the 156 recoded binary issues also reveals a multidimensional issue space. The set of ideal points on the first dimension produced by NOMINATE correctly predicts $77.7 \%$ of responses by the 28 actors, and the second dimension correctly predicts an additional $3.9 \%$ of responses. ${ }^{4}$ These sound like relatively high figures. But, the percentage of responses explained under NOMINATE cannot be compared directly with the percentage of variance explained by factor analysis. Moreover, these percentages are in fact rather low. For example, the first dimension of NOMINATE explains more than $85 \%$ of vote decisions in the US Congress and European Parliament and more than $90 \%$ of decisions in the United 
Nations General Assembly. In other words, this NOMINATE result supports the result from the exploratory factor analysis - that inductive techniques suggest a high degree of dimensionality in the IGC issue space.

Figure 3 shows the ideal point estimates produced by the application of NOMINATE to the IGC issue data. As we discussed, unlike factor analysis, it is difficult to interpret the substantive meaning of each of the dimensions produced by NOMINATE. Nevertheless, the location of Belgium, Germany and the two supranational institutions (the Commission and the European Parliament) at the extreme of the first dimension suggests that this dimension might relate to general attitudes of actors towards European integration. Also, this dimension may have something to do with the battle between big states and small states, because all the large states except Poland are towards the right end of this dimension.

Nevertheless, several actors' positions seem rather surprising. For example, the United Kingdom is located relatively close to the supranational institutions on both dimensions and a long way from actors that one would think have similar preferences on EU reforms, such as Denmark, Sweden or Ireland. Similarly, France is close to the supranational institutions on the first dimension, and

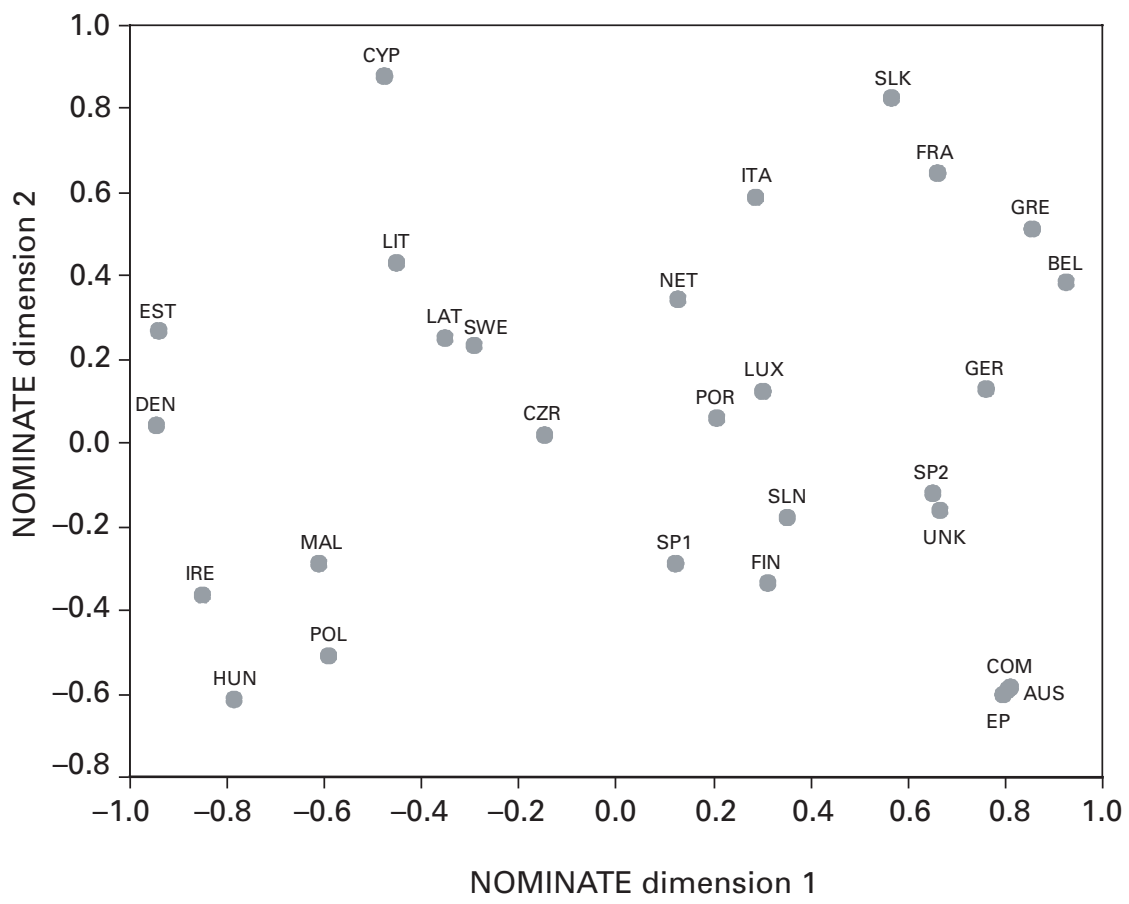

Figure 3 Ideal point estimates using NOMINATE. 
close to highly integrationist states such as Belgium and Italy on both dimensions. Spain and Poland also appear in rather centrist positions on both dimensions, as they did in the figure produced by the exploratory factor analysis.

Optimal Classification does somewhat better than NOMINATE in the extent of actors' preferences classified correctly by two dimensions - although one must be careful in comparing the variance reduction statistics of these two methods. Using Optimal Classification, the first two dimensions of ideal point estimates classify $86.4 \%$ of actors' preferences on the 156 response items in the recoded survey data. ${ }^{5}$ Nevertheless, this is a comparatively low figure compared with the application of Optimal Classification to other parliaments, where over $90 \%$ of decisions (or preferences) are routinely classified correctly by two dimensions using this method (Poole, 2000). In other words, even Optimal Classification, which, unlike the other two methods, primarily aims to maximize the number of decisions classified correctly, still fails to capture about $14 \%$ of actors' preferences in two dimensions.

Figure 4 shows the ideal point estimates produced by the application of Optimal Classification to the IGC issue data. Not surprisingly, given the similar underlying metrics of Optimal Classification and NOMINATE, this figure is relatively similar to the NOMINATE figure. Nevertheless, there are

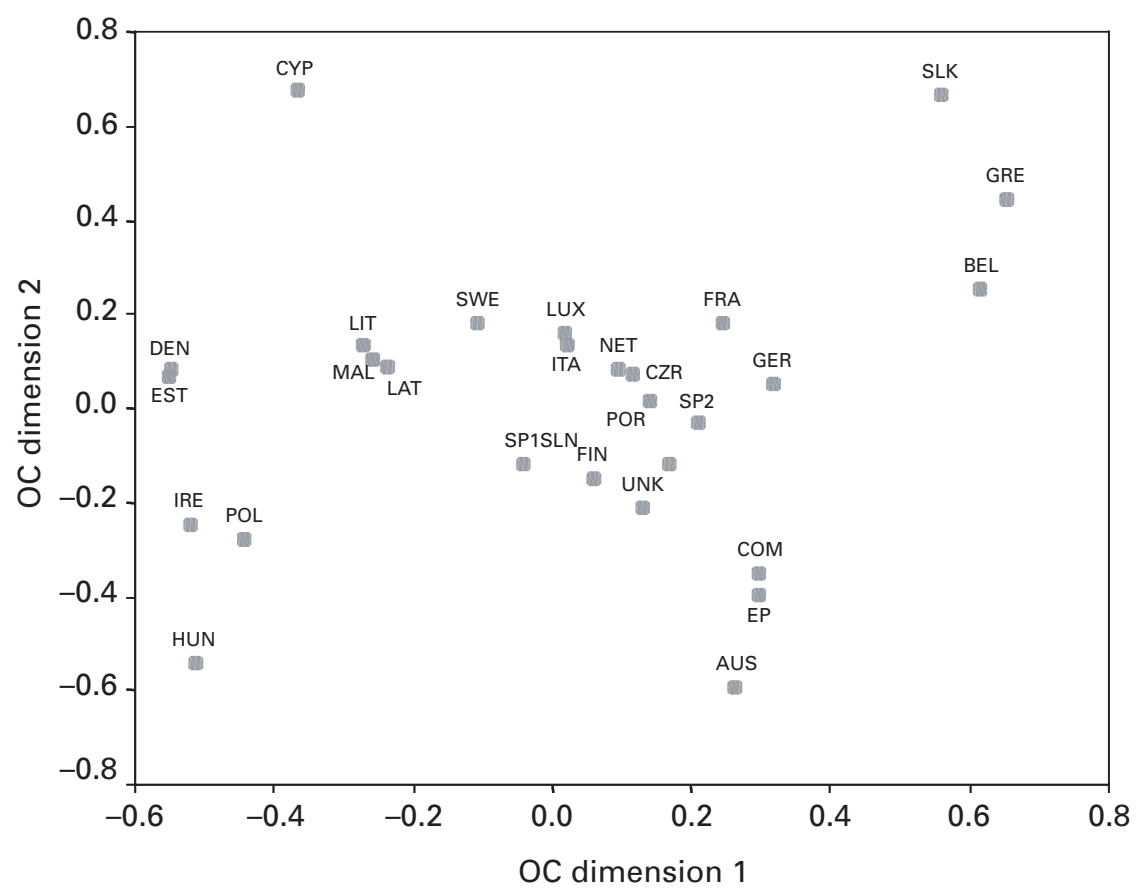

Figure 4 Ideal point estimates using Optimal Classification. 
some interesting differences in the relative locations of some of the actors. In the Optimal Classification figure, the Commission and European Parliament are not at the extreme on the first dimension; Germany, Belgium, Slovakia and Greece appear to have more extreme positions. Also, Poland occupies a relatively extreme position (although the first Spanish government does not), and France and Germany appear closer together, which could perhaps be expected given the attempts by these two states to coordinate their positions in the IGC negotiations. Three of the small new member states - Latvia, Lithuania and Malta - appear to have extremely similar positions. Nevertheless, the positions of the United Kingdom and France, close to the centre of the figure, do not fit our a priori assumptions. Again, as with NOMINATE, it is difficult to say much about the likely substantive content of the dimensions produced by Optimal Classification by simply 'eye-balling' the figure.

In sum, the application of these three inductive techniques to the preferences of actors in the IGC clearly illustrates that ideal point estimation is as much about art as about science. There are some similarities between the estimates produced by the three methods. But, there are also some striking differences, such as the position of the United Kingdom in the three figures - towards the bottom left in Figure 2, towards the bottom right in Figure 3, and almost exactly in the middle in Figure 4. Also, none of the three sets of inductively derived ideal point estimates accords well with our prior theoretical assumptions about the likely shape of the issue space in the IGC negotiations.

One possible reason for the rather strange set of ideal point estimates generated by these methods is that a large number of issues/items in the data set have a relatively low salience for many of the actors. All these methods, however, treat every preference equally. Hence, even if an issue is largely irrelevant, the location of actors on this issue is still used in the generation of the ideal points. This is not a problem if only a small number of issues is of low salience. But, where there is a high number of low-salience issues, as is the likely case here, the accumulated 'noise' from these issues will drown out the effect of the high-salience issues in the construction of the ideal point scores. As a result, a more deductive method is likely to generate more meaningful ideal points.

\section{Mixed deduction/induction: Factor analysis of two separated dimensions}

Building on the theoretical discussion of the likely underlying dimensions of constitutional design, we can separate the issues in the IGC into issues that 
relate to the (vertical) allocation of power between the EU and the member states and issues that relate to the (horizontal) allocation of power between the member states (in the Council) and the supranational institutions (the Commission, European Parliament and European Court of Justice).

The vertical dimension of constitutional design clearly covers issues related to the definition and policing of the competences of the EU (the Charter of Fundamental Rights, subsidiarity, the objectives of the Union, the religious reference, external representation and whether a particular policy competence should be allocated to the EU or the national level), and issues that define the extent of EU action in a particular policy field (the Stability and Growth Pact, defence policy, external borders and migration and asylum). Similarly, the freedom of states either to pursue further integration (enhanced cooperation) or to leave the EU (right to withdraw) also relates to this dimension, because it is about the rights of states vis-à-vis the centre. Finally, the battery of issues relating to majority voting in the Council should also be included as part of the vertical dimension (as well as the horizontal dimension) because the movement from unanimity to majority voting is the equivalent of shifting a policy competence from the national level to the European level, because a member state could veto any move from its domestic policy status quo under unanimity voting.

The horizontal dimension, in contrast, covers the nature of representation in, and appointment of, the European institutions (the design of QMV in the Council, the nature of the Presidency of the Council, the election of the Council President, the appointment of a Foreign Minister, the number of Commissioners, the appointment of the Commission President and the Commissioners, and the role of the European Parliament in the investiture of the Commission). The horizontal dimension also covers the powers of the European Court of Justice and the powers of the European Parliament (the policy areas covered by the co-decision procedure and the budgetary powers of the Parliament) and who has the right to initiate legislation (the Commission, the Parliament, the Council, national parliaments or EU citizens). Finally, the extension of qualified majority voting in the Council should also be included in the horizontal dimension because the move from unanimity to QMV in a particular policy area increases the agenda-setting power of the Commission and Parliament relative to the member states, and increases the likelihood that a policy status quo can be changed. In other words, the 12 issues in the data that relate to the extension of qualified majority voting are the only issues that we think clearly relate to both the vertical allocation of power (between the member states and the EU institutions) as well as the horizontal allocation of power (in terms of the ability to block or change policies at the European level). 
Table 2 presents the results of an exploratory factor analysis of the preferences of the 26 governments and the two EU institutions on the 36 issues identified as relating to the vertical dimension of constitutional design, again using the principal components factor method and varimax rotation. ${ }^{6}$ The first factor explains $18.4 \%$ of the variance in preferences on these issues and the second factor explains a further $14.0 \%$. Hence, these two factors together explain almost one-third of the variance in preferences on this subset of issues.

Moreover, the four issues that load highest on the first factor of the vertical dimension subset of issues were all highly salient issues for one or more member state, and relate to the protection of national sovereignty against a shift of policy-making power to the European level: majority voting on tax harmonization and social security (which were two of the United Kingdom's 'red-line' issues); whether macroeconomic policy should be allocated to the national or European level, and whether the Growth and Stability Pact should be made more flexible (France and Germany wanted more flexibility in return for more EU policy competences on economy policy, against the opposite view of many of the smaller member states).

The five issues that load highest on the second factor of this subset of issues were also relatively salient in the negotiations: the allocation of competences to the national or European level of agricultural, structural and cohesion, health and environmental policies, and the extent of European-level rules on the control of the EU's external borders.

Table 3 presents the results of an exploratory factor analysis of the preferences of the actors on the 35 issues identified as relating to the horizontal dimension of constitutional design. ${ }^{7}$ This time, the first factor explains $19.4 \%$ of the variance in preferences and the second factor explains a further $10.1 \%$. So, the first two factors together explain almost $30 \%$ of the total variance in preferences on this subset of issues.

Six of the seven issues with the highest loadings on the first factor on this horizontal dimension subset of issues relate to increasing the powers of the European Parliament over sensitive areas of EU policy: the extension of the co-decision procedure to defence policy, common foreign policy, social security, tax harmonization, economic policy, and monetary policy. The seventh issue, the extension of majority voting on social security, is the only issue that loads highly on the first factor of the horizontal dimension subset of issues as well as the first factor of the vertical dimension subset of issues.

The second factor on the horizontal dimension captures divisions on the extension of majority voting, where the issues with the highest loadings are majority voting on social security, common foreign policy, defence policy and tax harmonization, and the design of QMV in the Council. Two other issues also show up highly on this second factor: whether the initiative for 
Table 2 Factor loadings on the expected vertical dimension

\begin{tabular}{|c|c|c|}
\hline \multirow[b]{2}{*}{ Issue } & \multicolumn{2}{|l|}{ Factor } \\
\hline & 1 & 2 \\
\hline 1: Charter of Fundamental Rights & -.200 & .196 \\
\hline 2: Subsidiarity & -.051 & -.080 \\
\hline 3: Religious reference & .271 & -.153 \\
\hline 4: Right to withdraw from the Union & -.055 & .242 \\
\hline 5a: Objectives: Market economy & -.038 & -.164 \\
\hline 5b: Objectives: Employment & -.097 & .096 \\
\hline 5c: Objectives: Competitiveness & .098 & .054 \\
\hline 12: External representation & .085 & .386 \\
\hline 16: Enhanced cooperation & -.042 & .112 \\
\hline 17.1: Level of competence: Agriculture & -.110 & .842 \\
\hline 17.2: Level of competence: Structural and cohesion policies & -.149 & .717 \\
\hline 17.3: Level of competence: Area of freedom, security and justice & -.129 & -.217 \\
\hline 17.4: Level of competence: Foreign policy & -.240 & .108 \\
\hline 17.5: Level of competence: Economic policy & .409 & .191 \\
\hline 17.6: Level of competence: Tax harmonization & .161 & .199 \\
\hline 17.7: Level of competence: Employment policy & .078 & -.035 \\
\hline 17.8: Level of competence: Social policy & .305 & .167 \\
\hline 17.9: Level of competence: Health & .077 & .713 \\
\hline 17.10: Level of competence: Environment & .024 & .491 \\
\hline 17.11: Level of competence: Education & -.118 & .145 \\
\hline $\begin{array}{l}\text { 17.12: Level of competence: Research, technological development } \\
\text { and space }\end{array}$ & -.070 & .306 \\
\hline 18a.2: Majority voting: Structural and cohesion policies & .126 & -.150 \\
\hline 18a.3: Majority voting: Area of freedom, security and justice & .216 & -.199 \\
\hline 18a.5: Majority voting: Tax harmonization & .432 & -.125 \\
\hline 18a.6: Majority voting: Monetary policy (for the euro states) & -.341 & -.016 \\
\hline 18a.7: Majority voting: Economic policy & .060 & .113 \\
\hline 18a.8: Majority voting: Employment policy & -.205 & -.076 \\
\hline 18a.9: Majority voting: Social policy & .086 & -.358 \\
\hline 18a.10: Majority voting: Social security rights & .400 & -.117 \\
\hline 18a.11: Majority voting: Common foreign policy & .003 & -.272 \\
\hline 18a.12: Majority voting: Defence policy & .175 & .188 \\
\hline 20: Stability and Growth Pact: Flexibility & -.731 & .191 \\
\hline 21: Stability and Growth Pact: Debt criterion & -.134 & .094 \\
\hline 22: Defence & -.019 & -.041 \\
\hline 23: External borders & .000 & .509 \\
\hline 24: Migration and asylum & .273 & .062 \\
\hline
\end{tabular}

Note: Method - principal components factor analysis with varimax rotation. 
Table 3 Factor loadings on the expected horizontal dimension

\begin{tabular}{|c|c|c|}
\hline \multirow[b]{2}{*}{ Issue } & \multicolumn{2}{|l|}{ Factor } \\
\hline & 1 & 2 \\
\hline 6: Presidency of the European Council & .046 & -.006 \\
\hline 7: Election of the Council President & -.307 & .201 \\
\hline 8: Design of QMV & .069 & -.614 \\
\hline 9: Number of Commissioners & .066 & -.131 \\
\hline 10: Appointment of Commission President & .177 & -.012 \\
\hline 11: Appointment of Commissioners & .193 & -.200 \\
\hline 13a: Appointment of Foreign Minister & .108 & -.117 \\
\hline 13b: Additional approval by the EP & -.196 & .092 \\
\hline 14: ECJ jurisdiction & .216 & -.163 \\
\hline 15b: Initiative for legislative acts: Parliament & .303 & .468 \\
\hline 15c: Initiative for legislative acts: Council & -.258 & .219 \\
\hline 15e: Initiative for legislative acts: Citizens & -.013 & .091 \\
\hline 18a.2: Majority voting: Structural and cohesion policies & .179 & -.145 \\
\hline 18a.3: Majority voting: Area of freedom, security and justice & -.243 & -.265 \\
\hline 18a.5: Majority voting: Tax harmonization & .178 & -.813 \\
\hline 18a.6: Majority voting: Monetary policy (for the euro states) & .058 & -.071 \\
\hline 18a.7: Majority voting: Economic policy & .251 & -.088 \\
\hline 18a.8: Majority voting: Employment policy & .102 & -.108 \\
\hline 18a.9: Majority voting: Social policy & -.080 & -.380 \\
\hline 18a.10: Majority voting: Social security rights & .443 & -.604 \\
\hline 18a.11: Majority voting: Common foreign policy & .090 & -.657 \\
\hline 18a.12: Majority voting: Defence policy & .325 & -.784 \\
\hline 18b.1: Co-decision: Agriculture & .149 & .088 \\
\hline 18b.2: Co-decision: Structural and cohesion policies & .090 & .117 \\
\hline 18b.3: Co-decision: Area of freedom, security and justice & .088 & .228 \\
\hline 18b.4: Co-decision: Internal market & .099 & .430 \\
\hline 18b.5: Co-decision: Tax harmonization & .556 & -.259 \\
\hline 18b.6: Co-decision: Monetary policy (for the euro states) & .432 & .087 \\
\hline 18b.7: Co-decision: Economic policy & .458 & .002 \\
\hline 18b.8: Co-decision: Employment policy & .294 & -.198 \\
\hline 18b.9: Co-decision: Social policy & .273 & .015 \\
\hline 18b.10: Co-decision: Social security rights & .642 & -.225 \\
\hline 18b.11: Co-decision: Common foreign policy & .917 & -.132 \\
\hline 18b.12: Co-decision: Defence policy & .917 & -.132 \\
\hline 19: Budgetary rights of the EP & .125 & -.010 \\
\hline
\end{tabular}

Note: Method - principal components factor analysis with varimax rotation. 
legislative acts should be taken away from the European Parliament, and whether the co-decision procedure should continue to be applied to internal market legislation.

In other words, this mixed deductive/inductive method captures the substantive content of the two exogenous dimensions of constitutional design quite well, as many of the key issues on each dimension load highly on the respective first factors. Moreover, as Figure 5 shows, the extracted ideal point estimates from the factor loadings of all the issues on the first factor of each dimension accord closely with intuitive expectations about the location of the key actors on the vertical and horizontal allocation of power in the EU.

Specifically, the United Kingdom is revealed as having a classic 'intergovernmentalist' set of preferences - at the decentralization end of the vertical dimension, and towards the consensus side of the horizontal dimension. The position of France also accords with our expectations: pro-centralization of policy competences, but in favour of intergovernmental institutions at the European level. Against these two, Belgium, the European Parliament and the Commission all reveal classic 'Euro-federalist' preferences, with a centralization of power and majoritarian institutions. Interestingly, Slovakia appears

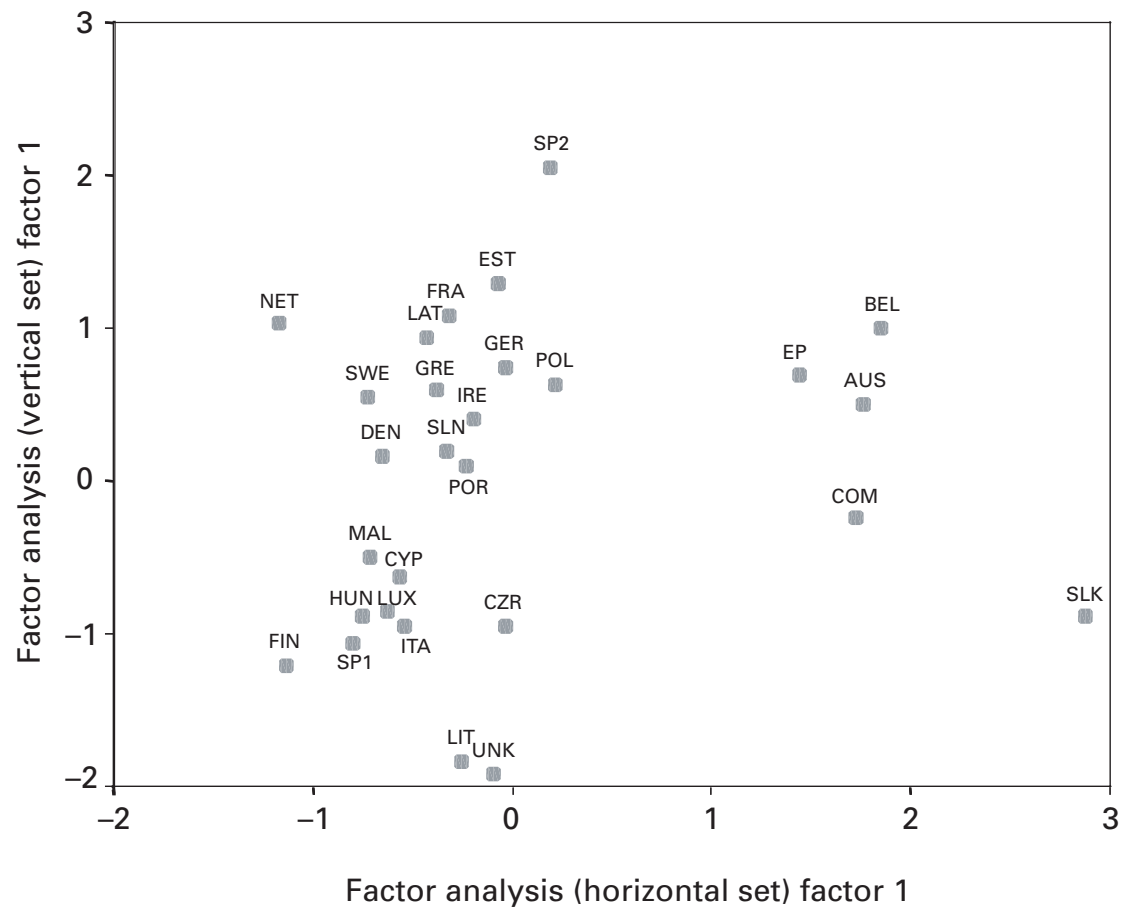

Figure 5 Ideal point estimates using a 'mixed' method. 
Table 4 Correlations between ideal point estimates

\begin{tabular}{|c|c|c|c|c|c|c|c|c|c|c|}
\hline & $\begin{array}{l}\text { Expl. FA } \\
\text { (full-set) } \\
\text { Factor } 1\end{array}$ & $\begin{array}{l}\text { Expl. FA } \\
\text { (full-set) } \\
\text { Factor } 2\end{array}$ & $\begin{array}{l}\text { NOM. } \\
\text { Dim. } 1\end{array}$ & $\begin{array}{l}\text { NOM. } \\
\text { Dim. } 2\end{array}$ & $\begin{array}{l}\text { OC } \\
\text { Dim. } 1\end{array}$ & $\begin{array}{l}\text { OC } \\
\text { Dim. } 2\end{array}$ & $\begin{array}{l}\text { Vertical } \\
\text { subset } \\
\text { Factor } 1\end{array}$ & $\begin{array}{l}\text { Vertical } \\
\text { subset } \\
\text { Factor } 2\end{array}$ & $\begin{array}{l}\text { Horizontal } \\
\text { subset } \\
\text { Factor } 1\end{array}$ & $\begin{array}{l}\text { Horizontal } \\
\text { subset } \\
\text { Factor } 2\end{array}$ \\
\hline Exploratory factor analysis (full set) factor 1 & 1.000 & & & & & & & & & \\
\hline Exploratory factor analysis (full set) factor 2 & .000 & 1.000 & & & & & & & & \\
\hline NOMINATE dimension 1 & $.548^{* *}$ & -.086 & 1.000 & & & & & & & \\
\hline NOMINATE dimension 2 & .095 & .299 & .043 & 1.000 & & & & & & \\
\hline Optimal Classification dimension 1 & $.480 * *$ & .016 & $.941 * *$ & .189 & 1.000 & & & & & \\
\hline Optimal Classification dimension 2 & -.019 & $.473^{*}$ & -.001 & $.916 * *$ & $* .195$ & 1.000 & & & & \\
\hline Vertical subset factor 1 & .215 & -.122 & .112 & .016 & .122 & -.023 & 1.000 & & & \\
\hline Vertical subset factor 2 & -.032 & $.843^{* *}$ & -.035 & .325 & .027 & .362 & .000 & 1.000 & & \\
\hline Horizontal subset factor 1 & -.019 & .050 & $.489 * *$ & -.058 & $.528 * *$ & $* .044$ & .136 & .159 & 1.000 & \\
\hline Horizontal subset factor 2 & $-.864 * *$ & .155 & $-.481 * *$ & -.111 & $-.426^{*}$ & .043 & $-.382^{*}$ & .071 & .000 & 1.000 \\
\hline
\end{tabular}

Note: Persson correlation coefficients.

** significant at .01 level (2-tailed); * significant at .05 level (2-tailed). 
to be the only member state with the fourth ideal-typical combination of preferences: favouring a decentralization of policy competences but majoritarian institutions in the EU. As regards other actors, the location of the two Spanish governments captures the shift in position from the Aznar to the Zapatero government, from a classic intergovernmentalist position to a considerably more pro-integrationist stance (on the vertical dimension) and a more moderate view on the allocation of powers to the Commission and the European Parliament (on the horizontal dimension).

\section{Correlation between the ideal point estimates}

To compare the ideal point estimates produced by the inductive and mixed methods, Table 4 shows the correlations between the ideal points on the first two dimensions 'discovered' by each method. The table in the appendix contains the actual ideal point estimates for the 28 actors on each of these 10 dimensions. ${ }^{8}$

The results illustrate that the methods produced quite different sets of estimates. Interestingly, the estimates on each of the first dimensions produced by the three inductive methods are highly correlated. Also, the inductive methods did pick up some of the variations identified in the two sets of mixed dimensions. For example, the ideal points from the first factor derived from the horizontal subset of issues are highly correlated with the first dimension of NOMINATE coordinates and the first dimension of Optimal Classification coordinates. The ideal points from the second factor derived from the vertical subset of issues are also highly correlated with the second factor scores from the exploratory factor analysis. Nevertheless, no other set of coordinates is correlated with the set of ideal points on the first factor from the vertical subset of questions - the other main dimension produced by our mixed method.

\section{Conclusion}

In this article we studied the preferences of the EU governments and the supranational institutions on the principal dimensions of conflict during the negotiations on an EU Constitution. We used the DOSEI data set and applied four alternative methods for deriving ideal point estimates for these actors on the main dimensions of conflict in the IGC negotiations. First, we applied three different inductive methods. These methods all revealed a comparatively high number of underlying dimensions in the issue space. Moreover, 
the actors' locations produced by these dimensions do not correspond well with our prior intuitions about the likely location of some of the key actors. In addition, the substantive content of the dimensions produced by these methods is hard to interpret.

Hence, we applied a mixed deductive/inductive factor analysis to see if we could produce a more intuitive set of estimates. Here, we consider two a priori dimensions in the constitutional debate, one related to the vertical allocation of power between the EU and the member states and the other related to the horizontal allocation of power between the EU institutions. We then applied factor analysis on the subset of issues that we identified as relating to these two dimensions. We found that this method explains significantly more variation than a purely inductive factor analysis. Moreover, the derived ideal point estimates from this method corresponded more closely to our prior intuitions about the likely location of some of the key actors and the substantive content of the main dimensions of competition in the IGC negotiations than did the results of the three inductive methods.

Obviously our analysis is not the definitive word on the measurement of preferences in the constitutional debate on the EU, but rather illustrates that any estimates produced are likely to be highly determined by the instrument one chooses to derive them. In terms of further research, we would recommend comparing our results produced by a variety of scaling methods with other, more exogenous, estimates of actors' ideal preferences in the constitutional debate, such as expert placement of actors on the key dimensions in EU politics (Ray, 1999; Marks and Wilson, 2000), the coding of parties' manifestos in recent national and European elections (Budge et al. 2001; Gabel and Hix, 2002), and the application of word scores to debates and texts in the Convention and the IGC (Laver et al., 2003). The comparison and combination of ideal point estimates derived from different techniques are likely to lead to considerably more reliable estimates of the positions of the key actors on the main underlying dimensions in the EU constitutional debate.

\section{Notes}

1 See the Americans for Democratic Action website, URL: http://www. adaction.org/votingrecords.htm. Each year the ADA selects 20 votes it considers the most important during that session, and each Congressperson receives 5 points if he/she voted the 'right way' according to the ADA, and does not receive 5 points if he/she voted against the ADA or was absent. The highest possible total is consequently 100 .

2 We use the version of the data set where missing responses are entered as equivalent to 'indifference' on an issue. 
3 Four issues were dropped in the analysis owing to zero variance on these issues: (15a) Initiative for legislative acts: Commission; (15d) Initiative for legislative acts: National parliaments; (18a.1) Majority voting: Agriculture; and (18a.4) Majority voting: Internal market.

4 We set NOMINATE to generate estimates on two dimensions. Setting a higher number of dimensions did not change the results significantly.

5 We set Optimal Classification to generate estimates on two dimensions. Setting a higher number of dimensions did not change the results significantly.

6 Two issues were dropped because of zero variance: (18a.1) Majority voting: Agriculture; and (18a.4) Majority voting: Internal market.

7 Four issues were dropped because of zero variance: (15a) Initiative for legislative acts: Commission; (15d) Initiative for legislative acts: National parliaments; (18a.1) Majority voting: Agriculture; and (18a.4) Majority voting: Internal market.

8 The appendix can be found on the EUP website.

\section{References}

Bentler, Peter M. (1990) 'Comparative Fit Indexes in Structural Models', Psychological Bulletin 107: 238-46.

Budge, Ian, Hans-Dieter Klingemann, Andrea Volkens and Judith Bara (2001) Mapping Policy Preferences: Estimates for Parties, Electors, and Governments, 1945-1998. Oxford: Oxford University Press.

Gabel, Matthew and Simon Hix (2002) 'Defining the EU Political Space: An Empirical Study of the European Elections Manifestos, 1979-1999', Comparative Political Studies 35: 934-64.

Hix, Simon (2001) 'Legislative Behaviour and Party Competition in European Parliament: An Application of Nominate to the EU', Journal of Common Market Studies 39(4): 663-88.

Laver, Michael, Kenneth Benoit and John Garry (2003) ‘Extracting Policy Positions from Political Texts Using Words as Data', American Political Science Review 97: 311-31.

Lijphart, Arend (1999) Patterns of Democracy: Government Forms and Performance in Thirty-Six Countries. New Haven, CT: Yale University Press.

Marks, Gary and Carole Wilson (2000) 'The Past in the Present: A Cleavage Theory of Party Positions on European Integration', British Journal of Political Science 30: 433-59.

Norman, Peter (2003) The Accidental Constitution: The Story of the European Convention. London: Gazelle.

Poole, Keith (2000) 'Non-Parametric Unfolding of Binary Choice Data', Political Analysis 8(2): 211-37.

Poole, Keith and Howard Rosenthal (1997) Congress: A Political-Economic History of Roll Call Voting. Oxford: Oxford University Press.

Powell, G. Bingham (2000) Elections as Instruments of Democracy: Majoritarian and Proportional Visions. New Haven, CT: Yale University Press. 
Ray, Leonard (1999) 'Measuring Party Orientations toward European Integration: Results from an Expert Survey', European Journal of Political Research 36(3): 283-306.

Rosenthal, Howard and Erik Voeten (2004) 'Analyzing Roll Calls with Perfect Spatial Voting: France 1946-1958', American Journal of Political Science 48(3): 620-32.

Schonhardt-Bailey, Cheryl (2003) 'Ideology, Party and Interests in the British Parliament of 1841-47', British Journal of Political Science 33: 581-605.

Taagepera, Rein (2003) 'Arend Lijphart's Dimensions of Democracy: Logical Connections and Institutional Design', Political Studies 51: 1-19.

Tsebelis, George (1995) 'Decision Making in Political Systems: Veto Players in Presidentialism, Parliamentarism, Multicameralism and Multipartyism', British Journal of Political Science 25: 289-325.

Tsebelis, George (2002) Veto Players: How Political Institutions Work. Princeton, NJ: Princeton University Press.

Voeten, Erik (2000) 'Clashes in the Assembly', International Organization 54(2): 185-216.

\section{About the authors}

Simon Hix is Professor of European and Comparative Politics in the Department of Government, London School of Economics and Political Science, Houghton Street, London WC2A 2AE, UK.

Fax: +44(0) 2079556532

E-mail: s.hix@lse.ac.uk

Christophe Crombez is Professor of Political Economy in the Department of Applied Economics, Katholieke Universiteit Leuven, Naamsestraat 69, 3000 Leuven, Belgium.

Fax: +3216326732

E-mail: Christophe.Crombez@econ.kuleuven.ac.be 